Thorpe, A., Snell, M., Hoskins, S. L, \& Bryant, J. (in press Higher Education

Quarterly) 'Universities are Not a Birthright of the Middle Classes': An Empirical Examination of the Role of Behavioural Constraints on Lower Social Class

Participation in Higher Education.

\title{
False Uniqueness: The Self-Perception of New Entrants to Higher Education in the UK and its Implications for Access - A Pilot Study
}

\author{
May 2006
}

\section{Andy Thorpe*, Martin Snell*, Sherria Hoskins** and Janet Bryant***}

(*Department of Economics, ** Department of Psychology, *** Department of Area and Language Studies), University of Portsmouth, UK.

Abstract: A central tenet of contemporary education policy relates to the desire to extend Higher Education provision to less advantaged groups ('widening participation'). Our paper contends that a key behavioural obstacle to widening participation lies in the erroneous belief that persists among potential entrants from disadvantaged backgrounds as to their capabilities of succeeding within the HE environment - a perception that serves to deflates application/recruitment rates from such groupings. We test this 'false uniqueness' thesis using a sample of 127 new UK undergraduates, finding that students drawn from lower social class backgrounds consistently under-estimated their abilities vis-à-vis the overall cohort.

JEL classification: I20, I28, D840.

Keywords: False Uniqueness, widening participation, education, university, social class. 
Corresponding Author: Dr. Andy Thorpe, Reader in Development Economics, Department of Economics, Portsmouth Business School, Richmond Building, Portland Street,

Portsmouth, PO1 3DE, Email address: Andy.Thorpe@port.ac.uk Tel: 02392844251 


\section{False Uniqueness: The Self-Perception of New Entrants to Higher Education in the UK and its Implications for Access: A Pilot Study ${ }^{1}$}

\section{Introduction}

Successive British governments have, over the last fifteen or so years, presided over the most dramatic expansion of Higher Education (HE) provision ever. In 1989 just 16 per cent of UK school-leavers went on to University. A decade later the number had climbed to 34 per cent, with current government HE strategies visualising a further expansion that will ensure a 50 per cent participation rate by 2010 (Greenaway and Haynes, 2003:152). This sharply increased participation in HE has been fuelled by a combination of demand and supply factors. Places offered by HE suppliers have grown as government policy decisions have embraced the principle of 'encouraging universities to increase their income by attracting more students’ (Baker, 1993:234), a principle facilitated by the introduction of common core funding mechanisms following the ending of the binary [polytechnic-university] divide in 1992 (Blanden and Machin, 2004:232). The concomitant growth in demand for university places has been variously attributed to a combination of improved examination results following the introduction of the General Certificate of Secondary Education in 1988 (Blanden et al., 2003) and a labour market that, in both demanding and rewarding those with graduate level qualifications (Machin, 1996; HECFE, 2001), has encouraged migration into the sector.

Nevertheless, while these factors have combined to ensure a marked increase in HE participation rates, attempts to extend $\mathrm{HE}$ access for historically

\footnotetext{
${ }^{1}$ The authors are grateful to Nick Adnett and Arnaud Chevalier for a number of helpful comments on an earlier version of this paper. Needless to say, responsibility for any remaining errors rests with the authors.
} 
disadvantaged/underrepresented groups have been rather less successful. The

Committee of Vice-Chancellors and Principals, for example, highlighted that while 80 per cent of young people from the top social class entered HE in 1997, just 14 per cent of those eligible from the lowest social class took the same career path. This 'social mix’ that, according to Greenaway and Haynes (2003:155), has scarcely altered since 1980, prompted the then Education Minister Estelle Morris to proclaim;

“...Universities are not a birthright of the middle classes. None of us can defend the position where five times as many young people from professional backgrounds enter higher education compared with those from unskilled or manual backgrounds ...

(Guildhall speech, October 2001).”

The most recent governmental response - the outcome-focussed Aimhigher initiative - is intended to redress this imbalance, identifying young people from lower socioeconomic groups as one of seven under-represented target groupings ${ }^{2}$ expected to benefit from activities designed to raise aspirations, improve educational attainment and smooth the transition into HE (HECFE, 2004:6). Aspirations - combined with ability - are crucial, particularly given the relatively higher degree of debt-aversion exhibited by lower social class (LSC) students $^{3}$ (Callender, 2003; Forsyth and Furlong, 2003). Yet while sociological theorising has commented upon how potential

\footnotetext{
${ }^{2}$ The others are people: from neighbourhoods with lower than average HE participation; living in deprived areas; whose family have no prior experience of HE; from ethnic minority groupings underrepresented in HE; who are disabled; and groups that are presently underrepresented - such as women in engineering - in certain subject areas (HECFE, 2004:12).

${ }^{3}$ Various categorisations of social class have been put forward over time, ensuring that this concept has a wide variety of meanings, depending on context and motivation. In this paper, we shall use the term in its most widely interpreted manner, referring to a continuous hierarchical categorisation within society, roughly relating to income and occupation. We use the acronym LSC to refer to those at the lower end of the spectrum.
} 
HE candidates from LSC backgrounds still perceive higher education to be exclusive ${ }^{4}$ - a birthright of the middle classes as it were - applied research in the area is limited (Connor et al., 2001:16), and detailed empirical examination of the issue is lacking.

We seek to remedy this oversight, exploring whether differences between perceptions of self and the academic environment provide an explanation for the continued low participation rates of LSC students in HE. Our research does not seek to identify who does (or does not) enter HE from a social class perspective, but more pertinently whether behavioural reasons may explain why LSC groups are under-represented in HE cohorts. Specifically we combine insights provided by Herbert Simon's notions of bounded rationality, the heuristics literature associated with Daniel Kahneman and Amos Tversky (1974) and the relatively neglected psychological concept of false uniqueness to argue that school leavers from LSC - notwithstanding the growing raft of preferential financial inducements offered and access programmes formulated - are still less likely to enter HE (once any inter-class differences in cognitive ability are taken into account), as relevant social referent frames for such groups continue to militate against entry.

The paper is organised in the following manner. First we derive theoretical justifications, based on individual perceptions about the normativeness of their (and, by implication LSC) behaviour and beliefs vis-à-vis HE, that affords insights into why present UK policy initiatives may be insufficient to redress the present class divide in HE. The second section of the paper describes the data and modelling strategies we

\footnotetext{
${ }^{4}$ Bourdieu and Passeron (1979:53), for example, acknowledge that those most removed from academic culture are also those most likely to feel alienated if placed within a student environment. As a consequence, a process of psychological self-exclusion may well exert itself (Bourdieu, 1986:471), causing those from LSC backgrounds to either discount applying to 'traditional universities' (Reay et al., 2001:863), or to reject the HE experience completely.
} 
have employed, while the following section details our results. A concluding section relates our findings to contemporary UK HE access widening strategies and suggests ways in which current initiatives could be enhanced with a view to augmenting the intake of school-leavers from LSC.

\section{2: $\quad$ Bounded Rationality, Heuristics and False Uniqueness as Explanatory Factors Underlying Differential Class Access Rates in HE.}

The work of Herbert Simon (1954) recognised that while economic agents may be rational in intent they may be less than rational in execution given cognitive constraints. Hence, while subjective expected utility theory is predicated upon a utility-maximising agent who chooses between a given (fixed) set of alternatives with subjectively known probability distributions associated with each outcome (Simon, 1987:266) - social reality is somewhat more complex: alternatives abound, the outcomes associated with each are uncertain, and human computational abilities are limited. A school-leaver, for example, not only has to make a choice on whether to enter HE or employment, but also on what institution to attend and what course to follow. Equally, the likely spectrum (and associated probabilities) of returns to attending university is uncertain ${ }^{5}$, as are notions regarding the levels of student income and expenditure whilst in HE (Callender, 2003:12). Faced with such a perplexing array of alternatives individuals are likely to act 'reasonably rather than rationally’ (Murphy, 2001:297) selecting a satisficing strategy, which fulfils some given aspiration level, over a utility-maximising one (Simon, 1955, 1956; Dequech,

\footnotetext{
${ }^{5}$ Dutta et al. (1999:378ff) estimated, for example, using 3,191 observations drawn from the 1995-6 General Household Survey, that aggregate private rates of return varied from $16.2 \%$ p.a for a business studies degree to a negative rate of return for a humanities degree.
} 
2001:913; Gabaix and Laibson, 2000:433).). The individual is thus boundedly rational, with the decision on whether to progress into HE depending "not only on the characteristics - sensory, neural, and other - of the [individual], but equally on the structure of the environment (Simon, 1956:130, the italics are ours).”

The individual's immediate environment offers a series of psychological cues (or heuristic shortcuts) when evaluating the probabilities associated with uncertain future events. The main shortcuts - which provide an explanation for why personal judgements may routinely deviate from those predicted by Bayesian probability theory - are those of availability, representativeness and anchoring/adjustment (Kahneman and Tversky, 1972; Tversky and Kahneman, 1973, 1974; Kahneman, 1992). The availability heuristic sees probabilities adjudged, and subsequent decisions made, by recourse to the 'ease with which instances or associations could be brought to mind' (Tversky and Kahneman, 1973:208). Representativeness, in contrast, uses similarity [to stereotypes or stereotypical behaviour] as a cue for assigning probabilities, while anchoring/adjustment involves individuals anchoring on information that is supplied, or readily comes to mind - and adjusting their subsequent responses in an appropriate direction [although adjustment is generally insufficient and decisions are overly influenced by ('anchored upon') the initially accessed information] (Altman, 2004:14; Epley and Gilovich, 2001:391). Such heuristics can lead to subjective probability bias, as individuals make judgements that are insensitive to statistical factors such as sample size, base rates and regression to the mean (Jones et al., 1995:110). 
These biases are particularly pertinent with regard to improving LSC access to HE. Low historic levels of HE participation in general - less than one-seventh of schoolleavers in the 1970s and early 1980s (Greenaway and Haynes, 2003:152), from which many of the current cohort of applicants are descended, went on to $\mathrm{HE}$ - and participation by parents of prospective candidates from LSC backgrounds in particular, have militated against the availability of familial precedents. Equally, instances like the widely reported Laura Spence $\operatorname{affair}^{6}$ can reinforce the idea among state school pupils that University education is essentially elitist [anchor/adjustment] - even if applying to Oxford to read medicine is perhaps an extreme example. In contrast, the recent dramatic expansion of HE will, over time, lead to a concomitant growth in the population holding a graduate qualification and, by offering a growing number of familial role models for LSC groupings, reduce the access-dampening effects of the availability heuristic. It will also encourage an enhanced perception of university as a natural progression for academically able school-leavers (UCAS, 2002:10) [representativeness], particularly if participation rates continue to rise towards the 50 per cent target espoused by the Labour government.

Nevertheless, while the stereotypical school-leaver is more likely to enter HE, the representativeness heuristic applied by an academically able school-leaver from a LSC background when confronted with the enter/not enter HE decision is more likely to be derived through recourse to a different sample subset of school-leavers. This sample subset are likely to have attended lower quality secondary education institutions, received less encouragement and educational instruction at home

\footnotetext{
${ }^{6}$ Spence, a state-school pupil, was rejected by Magdalen College Oxford (to read medicine) in 2000, despite gaining top grades in her A-level examinations. Her subsequent acceptance by Harvard (to read bio-chemistry) prompted the UK Chancellor Gordon Brown to describe the Oxford decision as 'absolutely scandalous', and precipitated an intense media debate on class inequalities and access to the elite UK universities.
} 
(Stinebrickner and Stinebrickner, 2003:593), suffer from a lack of familiarity with higher education (Forsyth and Furlong, 2003:52ff), and be more fearful of debt (Callender, 2003:44). These factors combine to deflate the educational aspirations and expectations of school-leavers from LSC backgrounds (Kinloch, 2001; Forsyth and Furlong, 2003:53).

Unfortunately, social comparison theory would suggest that this immediate environment to which the academically able LSC school-leaver relates is also likely to provide a reference frame which conditions perception of self and the judgement of one’s own abilities and opinions (Festinger, 1954; Morse and Gergen, 1970; Wood, 1989). While adaptive forces may encourage 'upward' comparison [with students at or intending to go on to University] and so encourage a desire for self-improvement and self-enhancement (Wood, 1989; Collins, 1996), there is also a latent threat that hedonic forces will dominate and the individual will revert to 'downward' comparisons [school-leavers from the same sample sub-set who have no intention of entering HE] that stultify ambition and aspirations (Brickman and Janoff-Bulman, 1977). Yet by relating one's abilities and accomplishments to those displayed by individuals less academically able than ourselves, downward comparison can promote feelings of superiority and confidence, raise one’s own self-esteem, and dilute ambition and aspirations. Consequently, by choosing the security of our own class peer group, we:

“... associate with people who share our background, experiences, interests, values, outlook. Our associates ... respond as we would in a variety of circumstances. Such shared characteristics may, in fact, provide the basis for association; indeed, we may 
be inclined to deliberately avoid those whom we believe unlikely to share our judgements and responses (Ross et al., 1977:298).”

This selective exposure not only conditions perceptions of self it also, in turn, offers a reference frame for evaluating others. Unfortunately such judgements are often suspect (McFarland and Miller, 1990:475). An extensive literature shows that individuals 'tend to perceive a false consensus for their own beliefs, attitudes, and behaviours' (see Marks and Miller, 1987, for a summary of research on the theme). This effect, rooted in the heuristic shortcuts alluded to above, leads individuals to see their own choices and judgements as relatively more common and/or appropriate than they really are and, in the current context, is epitomised by statements such as; 'People from our working class don’t go onto higher education' (applicant, cited in UCAS, 2002:10).' Of more interest to us in the current context however is the false uniqueness effect (FUE), which was first noted by Perloff and Brickman (1982). The FUE arises when individuals under- or overestimate the uniqueness of self-other similarity, seeing themselves as more happy (Andrews and Withey, 1976), intelligent (Wylie, 1979), ethical (Baumhart, 1968), desirable (Alicke, 1985), and less prejudiced (Lenihan, cited by McFarland and Miller, 1990) than others. Biernat et al. (1997:255) suggest the phenomena is more likely to be found in judgements of talent, ability or other desirable characteristics, while Marks and Miller (1987:85) stress the ability dimension - noting that college students frequently construed themselves to be more able [unique] than their peers.

Our paper contends that differential construal of aptitude and abilities in a HE sense can be explicitly linked to the [bounded] expectations associated with the reference 
group to which the potential HE recruit pertains. If HE entry expectations are low for particular social groups (such as LSC households), recruits from such groupings are likely to perceive themselves as relatively unique - and under-estimate their ability vis-à-vis the general student population. This of course has important implications not only for the personal decision of whether or not to enter HE, but equally in terms of formulating effective (access-enhancing and retention ${ }^{7}$ ) policy responses to counter such a bias. The following sections test for the existence of a FUE bias among new HE entrants drawn from LSC backgrounds.

\section{Methodology and Data.}

A series of Induction week announcements made across three faculties at the University of Portsmouth at the start of Academic Year 2004/5 (October 2004) invited newly enrolled first year undergraduate students to turn up to pre-booked computer rooms (where a member of the research team was present) and complete an on-line questionnaire in return for a $£ 5$ participation fee and free entry into a draw for a $£ 100$ prize. Newly enrolled undergraduates were targeted as the likelihood of the FUE was thought to be higher in such cohorts given their limited knowledge of both University expectations and innate ability levels of fellow graduates at this early juncture in their student life. Students were informed at this point that their data would be confidential and that the purpose of the research was to discover whether factors such as socio-

\footnotetext{
${ }^{7}$ Thomas (2002:431), for example, argues that if 'students feel that they do not fit in', and the HE institutional habitus serves to reinforce feelings of alienation among students drawn from nontraditional backgrounds, they are more likely to withdraw early.
} 
economic status, gender and family background influenced students’ motivation, expectations and achievement at University. ${ }^{8}$

The questionnaire, which contained five sections, was completed individually and took approximately forty-five minutes. An introductory section solicited background information about the participant [sex, age, ethnicity, social class etc.]. Students were then presented with, and asked to complete - under specified time constraints shortened versions of the numeracy (mental arithmetic element only) and literacy skills tests which must be taken by all trainee primary and secondary level teachers in England $^{9}$. After completing the tests, students provided estimates of both their own performance in the tests as well as that of other students on the same degree programme. The final sections of the questionnaire asked students to volunteer further information relating to their academic background [number and grades of GCSEs/Alevels - and where sat, past familial experience with HE], motivation [questions relating to their motives for entering HE, preferred modes of studying etc.] and expectations [predicted future earnings, probability of self and others completing the degree programme]. A copy of the complete on-line questionnaire is available, upon request, from the authors.

\footnotetext{
${ }^{8}$ Students who elected to participate were provided with an Informed Consent Form - detailing the nature of the research, the procedure to be followed - upon arrival at the computer room and then logged-in to commence the questionnaire.

${ }^{9}$ We elected to use these tests, developed under the aegis of the UK Teacher Training Agency, as they have been carefully designed to cover core skills of literacy and numeracy - skills we would equally expect to be relevant for undertaking most HE courses. More details on these tests, and sample questions, can be encountered at the TTA web-site (http://www.tta.gov.uk/php/read.php?sectionid=112\&articleid=1224).
} 
A total of 127 students were recruited in this manner ${ }^{10}$, Table 1 providing descriptive statistics for the sample cohort.

\section{TABLE 1 about here.}

Various approaches to ascertaining the student's social class or socio-economic background are possible and this paper considers several. Firstly, students were asked to categorise themselves into one of four indicated social classes (from "Upper Class" to "Working Class") ${ }^{11}$. Social comparison theory suggests students are likely to use their immediate environment as a reference frame when categorising themselves and, given that these six categorisations may be somewhat less relevant for international students, we omitted such students from all subsequent analyses and tables.

A second approach linked information provided by the respondent on parental occupations to the Office of National Statistics (ONS) self-coded socio-economic classification of occupations so as to derive a further alternative indicator of a respondent's social class. Two other variables were employed as alternative indicators of the class background of the respondent ${ }^{12}$ - the educational achievements of the institution where the respondent completed their immediate pre-HE qualifications,

\footnotetext{
${ }^{10}$ Just over 50 percent of these recruits were commencing degrees in modern languages and related subjects. The other recruits were from Economics, Psychology and Hospitality and Leisure Management.

${ }^{11}$ The question was constructed in this way as UK students are familiar with such categorisations and acknowledging one is from a working-class environment does not have the negative nuances of admitting to being LSC. Consequently, although there is no direct one-to-one correspondence between LSC and any subset of the self-coded classes, we presume those who describe themselves as 'working class' are drawn largely form LSC groups.

${ }_{12}$ Although these four methods of categorisation are not unrelated, they capture different aspects of an individual's background.
} 
and the 'lifestyle type' classification of the local neighbourhood from whence the respondent hailed. ${ }^{13}$

We surmise then that, in the context of entry to HE, individuals from LSC backgrounds may (erroneously) believe that they are less capable of succeeding in HE - and because of this, are less likely to apply for admission. To investigate this hypothesis requires asking a sample of persons from different social groups about their perceptions of the "average” student at University. Provided an individual in the sample has not changed his/her a priori expectations about the capabilities of other students, it is immaterial whether the individual is sampled before or after a decision is made about whether to start a university degree course. Our sample of new arrivals at University is justified on these grounds. If the hypothesis is correct, then it is may well apply a fortiori to the many students who do not come to University at all, but our sample precludes this investigation. Further, if this hypothesis is true and is relevant for a significant number of LSC individuals then this would explain why such groups are less prevalent in HE (even if they are just as capable).

\section{Results}

In order to test for the presence of a FUE it is important to firstly control for inherent differences in ability - otherwise differences in perception could easily be attributable to actual differences in ability. It is frequently asserted, for example, that students

\footnotetext{
${ }^{13}$ The UK Government publishes the results of public examinations taken at different schools and colleges on an annual basis (Dept for Education and Skills, Post-16 Performance Tables 2003. http://www.dfes.gov.uk/performancetables/16to18_03.shtml), while MOSAIC classifies all households and neighbourhoods in Great Britain into 52 distinct "lifestyle types" that comprehensively describe socio-economic and socio-cultural behaviour. These are then aggregated into 12 groups. (see http://census.ac.uk/cdu/Datasets/Experian_data/gbmosaic.pdf)
} 
from more wealthy home backgrounds go to 'better' schools and so achieve higher examination grades (Feinstein, 2003; Machin and Vignoles, 2004:115; de Regt and Weenink, 2005) that, in turn, facilitate access to HE. However, within our sample there was no evidence to suggest that ability (defined narrowly through recourse to the respondents' A-level points scores) varied by class using the self-categorisation measure (TABLE 2) ${ }^{14}$.

\section{Table 2 about here.}

Considering 'ability' in a more general sense however, suggests four specific parameters are relevant for this particular study, namely:

(i) The individual's estimate of the mean ability level of the cohort $\left(\mathrm{x}_{\mathrm{C}}\right)$

(ii) The individual's estimate of their own ability $\left(\mathrm{x}_{\mathrm{I}}\right)$

(iii) The true mean ability level of the cohort $\left(\mu_{\mathrm{C}}\right)$

(iv) The true level of the individual's own ability $\left(\mu_{\mathrm{I}}\right)$

Various hypotheses relating to FUE could be formulated around these parameters. To consider the most appropriate ones, it is pertinent to decide on those variables that prospective students might use in their decision on whether to apply for university. It would seem probable, ceteris paribus, that the likelihood of applying is related to the distance between your own ability and that of the cohort for the course you are applying. In practice, it is students' estimates of both these variables, rather than the

\footnotetext{
${ }^{14}$ Using simple ANOVA. We also performed statistical tests on the other three social class categorisations and found no significant relationship between A-level point scores and class groups on any of the measures (using ANOVA and correlation approaches, as appropriate).
} 
true values, which will be relevant. For example, if you think your ability is 'considerably below' what you believe to be the mean of the student cohort, you might be disinclined to apply. If you believe you have passed the 'minimum threshold' of ability for the course, then this is unlikely to be an obstacle to your applying and other factors (such as university facilities) will become more important. ${ }^{15}$ 'Errors' can come about in two ways - either you are wrong in the assessment of your own ability, or you are wrong in your assessment of the cohort's ability distribution (or both). Random errors are inevitable - few individuals are going to be perfect in their estimations. What is important here is whether there are systematic errors between social classes.

Approximations to the true ability of both cohort $\left(\mu_{\mathrm{C}}\right)$ and individual $\left(\mu_{\mathrm{I}}\right)$ were obtained from the separate numeracy and literacy scores from participant responses in the questionnaire. Supplementary questions asked students to estimate both their own score $\left(\mathrm{x}_{\mathrm{I}}\right)$ and the mean score of the cohort $\left(\mathrm{x}_{\mathrm{C}}\right)$ in both the tests. The results are shown in TABLE 3 below (A maximum of 10 marks in each test were available). ${ }^{16}$

\section{Table 3 about here.}

Individuals clearly believed (on average) that their own performance was lower than the group of participating new students as a whole. 58\% of respondents thought their score was lower than what they believed to be the average literacy score ( $87 \%$ in the

\footnotetext{
${ }^{15}$ It is possible that over-estimation of abilities will also deter application - i.e. you believe you are overqualified for the course and would be more suited to one where the mean level of ability was higher. We do not consider this here.

${ }^{16}$ Due to a computer problem, some respondents' answers to two questions on the numeracy test were not recorded. For consistency with self-assessments, it has been assumed that these answers would have been correct. Thus tables and results showing numeracy test scores are overestimates.
} 
numeracy case), but just $14 \%$ of respondents thought they performed better ( $5 \%$ in the numeracy case). For this to be the case, the distribution of scores would have to be very skewed. In fact the distribution of literacy scores was reasonably symmetric with a coefficient of skewness of -0.12 (not so for the numeracy test, where the coefficient equalled +1.07), clearly indicating an inherent inconsistency (and impossibility) of individual responses compared to the population results. In complete contrast to this underestimation of their own performance compared to the group, the tendency when asked how they estimated their own scores per se was to overestimate this on average by about 1 mark from the 10 available.

To examine whether particular factors might consistently explain the extent to which students are inaccurate in their expectations requires measurement of both error types noted above. In the case where the students overestimate their own score a simple difference $\left(\mathrm{x}_{\mathrm{I}}-\mu_{\mathrm{I}}\right)$ or percentage error difference might suffice. Where students are inaccurate in their estimate of the cohort ability distribution, we take the estimated mean as indicative $\left(\mathrm{x}_{\mathrm{C}}\right)$. (As the true value of the cohort mean is fixed, although unknown, the true error itself is not actually relevant). The FUE postulates that those respondents from LSC backgrounds are more likely to overestimate cohort scores $\left(\mathrm{x}_{\mathrm{C}}\right)$ - and so feel they had performed disproportionately badly when compared to students drawn other backgrounds. This hypothesis is tested - along with other potential explanatory variables - in a multivariate regression framework, whose findings are shown below (Tables 4 and 5).

Tables 4 and 5 about here. 
Table 4 examines factors that might explain the extent to which students overestimate their own achievements on each of the two tests. Besides using the (four) selfexpressed social class variables (and taking the Upper Class/Upper Middle Class group as the base category), a number of other variables were used in this and the subsequent regression equations. These included dummy variables for sex (male $=1$ ), for degree being studied (Languages being the base category) and for whether a close relative had attended university.

In Table 4, family background variables were never significant - LSC participants proved to be just as inept in predicting their test scores as their more privileged counterparts. Indeed, few variables help explain these errors, whether measured absolutely or as a percentage error, with the F-test for the numeracy equation suggesting that none of the variables chosen was significant. There was a general finding that the higher the student's estimate of their score, then the greater was the level of over-estimation. Those with lower scores were better at predicting how well they had done (this applied to both literacy and numeracy tests). Inclusion of one variable which may be linked to the background of the student - the mean A-level point score of the college they attended before coming to University - did of necessity reduce the number of observations (as GCSE records at college level are only available for England), but there was evidence that the higher this score, then the more accurate the student's prediction of their performance in the literacy test (One possibility for this finding is that those students who attend a college with good examination results are more able to recognise their strengths and weaknesses in the literacy area). 
Table 5 shows the results of a regression analysis to examine key ${ }^{17}$ factors that might explain variations in students' beliefs about the performance of their cohort. Despite the small sample size, the FUE is strongly confirmed independently for both the literacy and numeracy test expectations. Students from working class backgrounds estimated the average score for students starting on their degree to be significantly higher than did students from upper class backgrounds. The size of the coefficients for each of the groups 'middle class', 'lower middle class' and 'working class' suggested (particularly in the numeracy test) a steady increase in expectations as one progresses through these groups. Age was also a contributory factor - it would seem that the older the student, then the more literate and numerate they expect their peers to be. Given that the majority of students were in the 18-19 age band, it is likely that this reflects the (unfounded) worries of the mature students that they will not be up to the requirements of a degree course. In this respect the FUE hypothesis applies to them as well.

Table 5 also shows clear evidence that a student's own expectations of their performance in the tests (particularly in the numeracy test and - to a lesser degree - in the literacy test) very much determines how they think everyone else has done. The higher the score the student believed they had obtained in the test, then the greater their expectations regarding the scores of the remainder of their degree cohort (This works in both directions since those who thought they had done poorly in the tests also believed that others had done comparatively less well). To some extent, this suggests a false consensus effect perhaps is at work at the level of the test itself - and controls for the level of difficulty of the test. Students who believe the test to be hard

\footnotetext{
${ }^{17}$ The degree studied, attendance of a relative at University and actual test score achieved were also tested but found to be insignificant (and so have been excluded).
} 
will also assume that everyone else finds it hard too. They expect some correlation between their own performance and those of the rest of the cohort. ${ }^{18}$

\section{Conclusion.}

There is widespread belief that the 'social class gap in entry to HE remains unacceptably wide’ (Connor et al. 2001; Callender, 2003; Forsyth and Furlong, 2003) for:

“...the expansion of higher education has not yet extended to the talented and best from all backgrounds. In Britain today too many of those born into less advantaged families still see a university place as being beyond their reach, whatever their ability (Charles Clarke, Secretary of State for Education and Skills, HMSO, 2003:2).”

Widening participation has, consequently, become a leitmotif for educational policy makers and HE institutions alike, with Educational Maintenance Allowances (EMAs) ${ }^{19}$ and the Aimhigher Initiative being the latest in a series of national-local collaborations destined to raise aspirations, improve educational attainment and smooth the transition into HE. The greatest emphasis has not unnaturally focussed on

\footnotetext{
${ }^{18}$ The above analyses were repeated using the two alternative measures of social class noted above the Mosaic lifestyle and the ONS standard socio-economic classification - on each occasion having categorised into dummy variables. Where significant, these variables tended to be in line with the above commentary.

${ }^{19}$ The EMA scheme seeks to encourage 16 to 19 -year-olds from low income families to remain in post16 education through the provision of a means-tested payment (currently 30 pounds a week maximum). Estimates suggest the scheme, piloted in 1999 before being introduced nationally in September 2004, could increase the proportion of young people remaining in education by $8 \%$.
} 
the relatively higher degree of debt-aversion exhibited by LSC students - and there is already evidence emerging of fee remission, grant and/or bursary schemes being offered by some HE institutions to students from disadvantaged backgrounds to redress this. However, as Stinebrickner and Stinebrickner's (2001:594) research has shown in the USA, (expensive) tuition subsidy programmes alone may not equalise college graduation - or access - probabilities across income groups. While contemporary initiatives serve to ameliorate the impact of family background/environment, extending the pool of potential LSC applicants by reducing pre-HE income constraints (EMAs) and raising the aspirations of LSC groupings (Aimhigher) for example, there remains the question of (self-) perception.

Our paper considers the premise that, these initiatives notwithstanding, there remains some residual foreboding among LSC groups that may still cause psychological selfexclusion from HE. The ethos surrounding academia leads us to pre-suppose this will manifest itself through students from LSC backgrounds perceiving themselves to be (falsely) unique - under-estimating their own academic abilities vis-á-vis the general student population. We tested this hypothesis by inviting 127 new first year undergraduates to complete a questionnaire that included both literacy and numeracy tests, asking them to adjudge how well both they and their peers had fared. Although ability, as reflected in A-level points scores, was distributed equally across all class groupings, LSC (and mature) students consistently perceived other students on their degree programme to have performed relatively better than themselves in both numeracy and literacy tests. 
A first research priority then will seek to confirm the results of this pilot survey through recourse to a larger sample of new HE recruits. At the same time, further research might examine whether the results outlined in this paper also apply to students of other subject-areas (and other universities) - where admissions criteria and cohorts may be different, particularly in terms of academic ability. Moreover, while this paper has focussed on access to HE from the perspective of social class disadvantage, the research could usefully be extended to examine whether other under-represented groups (such as disabled, ethnic minority students etc.) are also prone to a FUE. The research agenda could also be broadened to consider how HE attendance impacts upon LSC perceptions. Is the 'false uniqueness' apparent at induction dissipated over time as LSC entrants swap older class-based heuristics for newer meritocratic ones drawn from the HE experience? Or do fears about one’s underlying ability to graduate persist - contributing to higher student drop-out rates for those from LSC and other disadvantaged backgrounds?

In conclusion, our findings reveal important implications for both HE admissions and retention policy if the government is indeed to meet its widening participation targets. While raising the aspirations of LSC groupings (as evidenced by the aptly-named Aimhigher Initiative) - so that they come to view HE as a feasible and relevant opportunity rather than a dream - is imperative, it is equally necessary to address those (false) perceptions of self-uniqueness that continue to militate against LSC entry into HE. 


\section{Bibliography.}

Alicke,M.D. 1985. 'Global Self-Evaluation as Determined by the Desirability and Controllability of Trait Adjectives', Journal of Personality and Social Psychology, 49(6):1621-30.

Altman,M. 2004. 'The Nobel Prize in Behavioral and Experimental Economics: A Contextual Appraisal of the Contributions of Daniel Kahneman and Vernon Smith', Review of Political Economy, 16(1):3-41.

Andrews,F.M., Withey,S.B.1976. Social Indicators of Well-Being, Plenum Press: New York.

Baker,K. 1993. The Turbulent Years. My Life in Politics, Faber and Faber: London.

Baumhart,R. 1968. An Honest Profit, Holt, Rinehart and Winston: New York.

Biernat,M., Manis,M., Kobrynowicz,D. 1997. 'Simultaneous Assimilation and Contrast Effects in Judgements of Self and Others', Journal of Personality and Social Psychology, 73(2):254-69.

Blanden,J., Machin,S. 2004. 'Educational Inequality and the Expansion of UK Higher Education', Scottish Journal of Political Economy, 51(2):230-49.

Blanden,J., Goodman,A., Gregg,P., Machin,S. 2003. 'Changes in Educational Inequality', http://www.ippr.org.uk/research/files/team23/project159/changes\%20in\%20education al\%20inequality\%20ej\%20june\%202003\%20version\%20to\%20submit1.pdf, (Accessed 24 May 2004).

Bourdieu,P., Passeron,J-C.1979. The Inheritors: French Students and their Relations to Culture, University of Chicago Press: Chicago.

Bourdieu,P. 1986. Distinction, Cambridge University Press: Cambridge.

Brickman,P., Janoff-Bulman,R. 1977. 'Pleasure and Pain in Social Comparison', Social Comparison Processes: Theoretical and Empirical Perspectives, Suls,J.M., Miller,R.L. (Eds), Hemisphere Publishing Co: Washington D.C.

Callender,C. 2003. Attitudes to Debt: School Leavers and Further Education Student's Attitudes to Debt and Their Impact on Participation in Higher Education, Report for Universities UK and HECFE.

Collins,R.L. 1996. 'For Better or Worse: The Impact of Upward Social Comparison on Self-Evaluations’, Pyschological Bulletin, 119:51-69.

Connor, H., Dewson,S., Tyers,C., Eccles,J., Regan,J., Aston,J. 2001. Social Class and Higher Education: Issues Affecting Decisions on Participation by Lower Social Class Groups, Institute for Employment Studies, Research Report No.267. 
De Regt,A., Weenink,D. 2005. 'When Negotiation Fails: Private Education as a Disciplinary Strategy’, Journal of Education Policy, 20(1):59-80.

Dequech,D. 2001. 'Bounded Rationality, Institutions and Uncertainty', Journal of Economic Issues, XXXV(4):911-29.

Dutta,J., Sefton,J., Weale,M. 1999. 'Education and Public Policy’, Fiscal Studies, 20(4):351-86.

Epley,N., Gilovich,T. 2001. 'Putting Adjustment Back in the Anchoring and Adjustment Heuristic: Differential processing of Self-Generated and ExperimenterProvided Anchors', Psychological Science, 12(5):391-6 2001.

Feinstein,L. 2003. 'Inequality in the Early Cognitive Development of British Children in the 1970 Cohort', Economica, 70:73-97.

Festinger,L. 1954. 'A Theory of Social Comparison Processes', Human Relations, 7:117-40.

Forysth,A., Furlong,A. 2003. Losing Out? Socio-economic Disadvantage and Experience in Further and Higher Education, Policy Press/Joseph Rowntree Foundation: Bristol.

Gabaix,X., Laibson,D. 2000. ‘A Boundedly Rational Decision Algorithm', American Economic Association Papers and Proceedings, May, 433-8.

Gibbons, S, Machin,S. 2003. 'Valuing English Primary Schools', Journal of Urban Economics, 25:197-219.

Greenaway,D., Haynes,M. 2003. 'Funding Higher Education in the UK: The Role of Fees and Loans’, Economic Journal, 113:F150-67.

HEFCE. 2004. Aimhigher: Guidance Notes for Integration, LSC Circular 04/01, http://www.hefce.ac.uk/Pubs/hefce/2004/04_08/04_08.pdf, (Accessed 15 April 2005). http://www.hefce.ac.uk/pubs/hefce/2003/03_14.htm, (Accessed 1 July 2004).

HEFCE. 2001. The Wider Benefits of Education, Institute of Education (University of London) Report 01/46 for HECFE and the Smith Institute, http://www.hefce.ac.uk/pubs/hecfe/2001/01_46.htm, (Accessed 13 July 2004).

HESA (Higher Education Statistical Agency). N/d. Performance Indicators in Higher Education in the UK, 2002/3, http://www.hesa.ac.uk/pi/ (Accessed 2 January 2005).

HMSO. 2003. The Future of Higher Education, Government White Paper (cm 5735), January.

Jones,S.K, Jones,K.T., Frisch,D. 1995. 'Biases of Probability Assessment: A Comparison of frequency and Single-Case Judgements', Organizational Behavior and Human Decision Processes, 61(2):109-22. 
Kahneman,D. 1992. 'Reference Points, Anchors, Norms, and Mixed Feelings', Organizational Behavior and Human Decision Processes, 51: 296-312.

Kahneman,D., Tversky,A. 1972. 'Subjective Probability: A Judgement of Representativeness’, Cognitive Psychology, 3:430-54.

Kinloch,G.C. 2001. 'Social Class and Attitudes Toward Education', Journal of Social Psychology, 127(4):399-401.

McFarland,C., Miller,D.T.1990. 'Judgements of Self-Other Similarity: Just Like Other People, Only More So’, Personality and Social Psychology Bulletin, 16(3):47584.

Machin,S., Vignoles,A. 2004. 'Educational Inequality: The Widening SocioEconomic Gap’, Fiscal Studies, 25(2):107-28.

Machin,S. 1996. 'Wage Inequality in the UK', Oxford Review of Economic Policy, 13(1):47-64.

Marks,G., Miller,N. 1987. 'Ten Years of Research on the False-Consensus Effect: An Empirical and Theoretical Review’, Psychological Bulletin, 102(1):72-90.

Morris.E. 2001. Key Challenges of the Next Decade, Speech at London Guildhall University, DfES, 22 October.

Morse,S., Gergen,K.J. 1970. 'Social Comparison, Self-Consistency, and the Concept of Self', Journal of Personality and Social Psychology, 16:148-56.

Murphy,J.W. 2001. 'Reason, Bounded Rationality, and the Lebenswelt: Socially Sensitive Decision Making’, American Journal of Economics and Sociology, 51(3):293-304.

Newsam,P. 2002. 'Diversity and Admissions to English Secondary Schools', edited version of a talk given at the Conference of the Secondary Heads Association, 28 June (Forum, 45[1]:17-18]).

Perloff,L.S., Brickman,P. 1982. 'False Consensus and False Uniqueness: Biases in Perceptions of Similarity’, Academic Psychology Bulletin, 4:475-94.

Reay,D., Davies,J., David,M., Ball,S.J. 2001. 'Choices of Degree or Degrees of Choice? Class, 'Race' and the Higher Education Choice Process', Sociology, 35(4):855-74.

Ross,L.Greene,D., House,P. 1977. 'The "False Consensus Effect”: An Egocentric Bias in Social Perception and Attribution Processes', Journal of Experimental Social Psychology, 13:279-301.

Simon,H. 1987.'Bounded Rationality', The New Palgrave Dictionary of Political Economy, Eatwell, J., Newman,P., Milgate,M. (Eds), MacMillan Press: London. 
Simon,H. 1956.'Rational Choice and the Structure of the Environment', Psychological Review, 63:129-38.

Simon,H. 1955. 'A Behavioural Model of Rational Choice’, Quarterly Journal of Economics, 69:99-118.

Simon,H. 1954. 'Banwagon and Underdog Effects and the Possibility of Election Predictions’, Public Opinion Quarterly, 18:245-53.

Stinebrickner,R., Stinebrickner,T.R. 2003. 'Understanding Educational Outcomes of Students from Low-Income Families: Evidence from a Liberal Arts College with a Full Tuition Subsidy Progam', Journal of Human Resources, XXXVIII(3):591-617.

Thomas,L. 2002. 'Student Retention in Higher Education: The Role of Institutional Habitus’, Journal of Education Policy, 17(4):423-42.

TTA (Teacher Training Agency). N/d. The QTS Skills Tests, http://www.tta.gov.uk/php/read.php?sectionid=112\&articleid=1224 (Accessed 16 September 2004).

Tversky,A., Kahneman,D. 1974. 'Judgement under Uncertainty: Heuristics and Biases, Science, 185:1124-31.

Tversky, A., Kahneman,D. 1973. 'Availability: A Heuristic for Judging Probability', Cognitive Psychology, 5:207-32.

UCAS. 2002. Paving the Way (Project Report), http://www.ucas.ac.uk/candq/paving/index.html, (Accessed 28 July 2004).

Wood,J.V. 1989. 'Theory and Research Concerning Social Comparisons of Personal Attributes’, Psychological Bulletin, 106(2):231-48.

Wylie,R.C. 1979. The Self-Concept: Theory and Research on Selected Topics, University of Nebraska Press: Lincoln. 
TABLE 1: Descriptive Statistics of the Sample.

\begin{tabular}{|c|c|c|c|}
\hline & & No. & $\%$ \\
\hline Sex & $\begin{array}{l}\text { Male } \\
\text { Female }\end{array}$ & $\begin{array}{l}57 \\
70\end{array}$ & $\begin{array}{l}45 \\
55\end{array}$ \\
\hline $\begin{array}{l}\text { How would you describe } \\
\text { your ethnic background }\end{array}$ & $\begin{array}{l}\text { White-British } \\
\text { White-Other } \\
\text { Black/Black British } \\
\text { Far East - Chinese } \\
\text { Other }\end{array}$ & $\begin{array}{c}87 \\
22 \\
7 \\
5 \\
6\end{array}$ & $\begin{array}{l}69 \\
17 \\
6 \\
4 \\
5\end{array}$ \\
\hline $\begin{array}{l}\text { If you were asked to say } \\
\text { which background you } \\
\text { have come from, which } \\
\text { of these categories do } \\
\text { you think fits best? }\end{array}$ & $\begin{array}{l}\text { Upper Class } \\
\text { Upper Middle Class } \\
\text { Middle Class } \\
\text { Lower Middle Class } \\
\text { Upper Working Class } \\
\text { Working Class } \\
\text { Don't know }\end{array}$ & $\begin{array}{l}3 \\
20 \\
52 \\
20 \\
9 \\
14 \\
9\end{array}$ & $\begin{array}{l}2 \\
16 \\
41 \\
16 \\
7 \\
11 \\
7\end{array}$ \\
\hline $\begin{array}{l}\text { National Statistics self- } \\
\text { coded Socio-economic } \\
\text { classification ('Highest' } \\
\text { of Respondent's mother } \\
\text { and/or father) }\end{array}$ & $\begin{array}{l}\text { Managerial and professional } \\
\text { occupations } \\
\text { Intermediate occupations } \\
\text { Small employers and own } \\
\text { account workers } \\
\text { Lower supervisory and } \\
\text { technical occupations } \\
\text { Semi-routine and routine } \\
\text { occupations } \\
\text { Unpaid household worker } \\
\text { Not given }\end{array}$ & $\begin{array}{l}86 \\
9 \\
13 \\
6 \\
\\
3 \\
8 \\
2\end{array}$ & $\begin{array}{l}68 \\
7 \\
10\end{array}$ \\
\hline Special Needs & $\begin{array}{l}\text { Dyslexia } \\
\text { Other Disabilities }\end{array}$ & $\begin{array}{l}7 \\
4 \\
\end{array}$ & $\begin{array}{l}6 \\
3 \\
\end{array}$ \\
\hline Home Location & $\begin{array}{l}\text { UK } \\
\text { Other European } \\
\text { International }\end{array}$ & $\begin{array}{l}104 \\
14 \\
9\end{array}$ & $\begin{array}{l}82 \\
11 \\
7\end{array}$ \\
\hline Age & $\begin{array}{l}18-19 \\
20-21 \\
22-24 \\
25 \text { and over }\end{array}$ & $\begin{array}{r}91 \\
16 \\
11 \\
6\end{array}$ & $\begin{array}{l}72 \\
13 \\
9 \\
5\end{array}$ \\
\hline $\begin{array}{l}\text { Close Relative has } \\
\text { studied/is studying at a } \\
\text { University }\end{array}$ & $\begin{array}{l}\text { Yes } \\
\text { No }\end{array}$ & $\begin{array}{l}69 \\
58\end{array}$ & $\begin{array}{l}54 \\
46\end{array}$ \\
\hline Sample Size & \multicolumn{3}{|l|}{127} \\
\hline
\end{tabular}


TABLE 2: A-level point scores and family background

\begin{tabular}{|c|c|c|c|c|c|c|}
\hline & \multicolumn{4}{|c|}{ Self-categorised family background } & \multirow[b]{2}{*}{ TOTAL } \\
\hline & & $\begin{array}{l}\text { Upper } \\
\text { Class/ } \\
\text { Upper } \\
\text { Middle } \\
\text { Class }\end{array}$ & $\begin{array}{l}\text { Middle } \\
\text { Class }\end{array}$ & $\begin{array}{l}\text { Lower } \\
\text { Middle } \\
\text { Class }\end{array}$ & $\begin{array}{l}\text { Upper } \\
\text { Working } \\
\text { Class } \\
\text { /Working } \\
\text { Class }\end{array}$ & \\
\hline \multirow{3}{*}{$\begin{array}{l}\text { A-level } \\
\text { equivalent } \\
\text { points score }\end{array}$} & Mean & 261 & 241 & 281 & 291 & 262 \\
\hline & $\begin{array}{l}\text { Standard } \\
\text { deviation. }\end{array}$ & 105 & 84 & 71 & 100 & 90 \\
\hline & $\mathrm{N}$ & 15 & 37 & 16 & 17 & 85 \\
\hline
\end{tabular}

Excludes cases where no A-level equivalent qualifications were recorded 
TABLE 3: Literacy And Numeracy Test Results And Expectations

\begin{tabular}{|c|c|c|c|c|}
\hline & \multicolumn{2}{|l|}{ Literacy } & \multicolumn{2}{|l|}{ Numeracy } \\
\hline Question asked & $\begin{array}{l}\text { Sample } \\
\text { mean }\end{array}$ & $\begin{array}{l}\text { Sample } \\
\text { standard } \\
\text { deviation }\end{array}$ & $\begin{array}{l}\text { Sample } \\
\text { mean }\end{array}$ & $\begin{array}{l}\text { Sample } \\
\text { standard } \\
\text { deviation }\end{array}$ \\
\hline $\begin{array}{l}\text { Please indicate what you } \\
\text { think your score was }\left(\mathrm{x}_{\mathrm{I}}\right)\end{array}$ & 5.8 & 1.9 & 3.2 & 1.7 \\
\hline $\begin{array}{l}\text { Please indicate what you } \\
\text { think the average score } \\
\text { was of NEW STUDENTS } \\
\text { ON YOUR DEGREE }\left(\mathrm{x}_{\mathrm{C}}\right)\end{array}$ & 7.1 & 1.6 & 5.7 & 1.6 \\
\hline True score achieved $\left(\mu_{\mathrm{I}}\right)$ & $\begin{array}{l}4.6 \\
(=\text { true } \\
\text { average } \\
\text { score of } \\
\left.\text { cohort }\left(\mu_{\mathrm{C}}\right)\right)\end{array}$ & 1.7 & $\begin{array}{l}2.0 \\
(=\text { true } \\
\text { average } \\
\text { score of } \\
\left.\text { cohort }\left(\mu_{\mathrm{C}}\right)\right)\end{array}$ & 1.8 \\
\hline
\end{tabular}

$\mathrm{N}=104$ 
Table 4: Errors in Estimation of Own Performance

\begin{tabular}{|c|c|c|c|c|c|c|c|c|}
\hline & \multicolumn{4}{|c|}{ Literacy } & \multicolumn{4}{|c|}{ Numeracy } \\
\hline Dependent Variable & \multicolumn{2}{|l|}{$\mathbf{x}_{1}-\mu_{1}$} & \multicolumn{2}{|c|}{$\left(x_{1}-\mu_{I}\right) / \mu_{I}$} & \multicolumn{2}{|c|}{$\mathbf{x}_{\mathbf{l}}-\mu_{1}$} & \multicolumn{2}{|c|}{$\left(x_{1}-\mu_{l}\right) / \mu_{1}$} \\
\hline Variable & Coeff. & $\begin{array}{l}\text { P- } \\
\text { Value } \\
\end{array}$ & Coeff. & $\begin{array}{l}\text { P- } \\
\text { Value } \\
\end{array}$ & Coeff. & $\begin{array}{l}\text { P- } \\
\text { Value }\end{array}$ & Coeff. & $\begin{array}{l}\text { P- } \\
\text { Value } \\
\end{array}$ \\
\hline Constant & 2.098 & 0.15 & 3.748 & 0.06 & 2.591 & $0.03 *$ & -0.637 & 0.51 \\
\hline $\begin{array}{l}\text { Own Estimate of Test } \\
\text { Score }\end{array}$ & 0.618 & $0.00 * *$ & 0.154 & $0.04 *$ & 0.284 & $0.02 *$ & 0.253 & $0.04 *$ \\
\hline Sex & 0.874 & $0.00 * *$ & 0.065 & 0.83 & -0.111 & 0.66 & 0.128 & 0.59 \\
\hline Age & -0.064 & $0.03 *$ & -0.054 & $0.04 *$ & -0.015 & 0.67 & 0.012 & 0.60 \\
\hline $\begin{array}{l}\text { Relative Studied at } \mathrm{HE} \\
\text { Institution }\end{array}$ & -0.450 & 0.15 & 0.096 & 0.72 & -0.033 & 0.91 & 0.246 & 0.34 \\
\hline $\begin{array}{l}\text { Mean A-level points of last } \\
\text { college attended }\end{array}$ & -0.011 & $0.00 * *$ & -0.010 & $0.05^{*}$ & -0.004 & 0.06 & 0.001 & 0.61 \\
\hline \multicolumn{9}{|l|}{ Family Background: } \\
\hline Middle Class & -0.346 & 0.48 & -0.337 & 0.27 & -0.768 & 0.14 & -0.361 & 0.32 \\
\hline Lower Middle Class & -0.590 & 0.32 & -0.102 & 0.86 & -0.712 & 0.24 & -0.002 & 0.99 \\
\hline $\begin{array}{l}\text { Upper Working } \\
\text { Class/Working Class }\end{array}$ & -0.960 & 0.08 & -0.802 & 0.09 & -0.850 & 0.10 & -0.582 & 0.12 \\
\hline \multicolumn{9}{|l|}{ Degree: } \\
\hline Economics & 0.018 & 0.97 & -0.574 & 0.22 & -0.498 & 0.21 & -0.132 & 0.69 \\
\hline Psychology & -0.010 & 0.98 & -0.479 & 0.17 & -0.690 & $0.04 *$ & 0.184 & 0.54 \\
\hline Hospitality/Leisure & -1.405 & $0.02 *$ & -1.232 & $0.03^{*}$ & -0.825 & 0.49 & 0.395 & 0.67 \\
\hline $\mathrm{N}$ & 77 & & 77 & & 77 & & 63 & \\
\hline Adj. R-Squared & 0.48 & & 0.086 & & 0.060 & & 0.000 & \\
\hline F test & 7.48 & $0.00 * *$ & 1.65 & 0.11 & 1.44 & 0.17 & 0.97 & 0.49 \\
\hline
\end{tabular}

P-values calculated using White-adjusted covariance matrix; ** Sig. at $1 \%$ level, * Sig. at 5\% level 
Table 5: Errors in Estimation of Cohort Performance.

\begin{tabular}{|l|l|l|l|l|}
\hline & \multicolumn{2}{l}{ Literacy } & \multicolumn{2}{l|}{ Numeracy } \\
\hline Dependent Variable & \multicolumn{2}{l|}{$\mathbf{X}_{\mathbf{C}}$} & & \\
\hline & & & & \\
\hline Variable & Coeff. & P-Value & Coeff. & P-Value \\
\hline & & & & \\
\hline Constant & 2.503 & $0.01^{* *}$ & -0.101 & 0.93 \\
\hline Own Estimate of Test Score & 0.186 & 0.06 & 0.406 & $0.00^{* *}$ \\
\hline Sex & -0.128 & 0.68 & 0.169 & 0.57 \\
\hline Age & 0.128 & $0.00^{* *}$ & 0.152 & $0.00^{* *}$ \\
\hline Mean A-level points of last college attended & -0.0002 & 0.93 & 0.002 & 0.14 \\
\hline Family Background: & & & & \\
\hline Middle Class & 1.383 & $0.02^{*}$ & 0.634 & 0.07 \\
\hline Lower Middle Class & 1.110 & 0.07 & 1.176 & $0.02^{*}$ \\
\hline Upper Working Class/Working Class & 1.530 & $0.00^{* *}$ & 1.317 & $0.00^{* *}$ \\
\hline & & & & \\
\hline N & 77 & & 77 & \\
\hline Adjusted R-Squared & 0.155 & & 0.275 & \\
\hline F test: F(7,69) & 2.99 & $0.01^{* *}$ & 5.12 & $0.00^{* *}$ \\
\hline
\end{tabular}

P-values calculated using White-adjusted covariance matrix; ** Sig. at $1 \%$ level, * Sig. at $5 \%$ level 